\title{
PAPER
}

Check for updates

Cite this: J. Anal. At. Spectrom., 2019, 34,1216

Received 23rd January 2019

Accepted 5th April 2019

DOI: $10.1039 / c 9 j a 00028 c$

rsc.li/jaas

\section{When gold stops glittering: corrosion mechanisms of René Lalique's Art Nouveau jewellery}

\author{
I. Tissot, (D)*ab J. Correia, (D) ${ }^{\text {c } O . ~ C . ~ M o n t e i r o, ~(D) ~}{ }^{c}$ M. A. Barreiros (iD) ${ }^{d}$ and M. F. Guerrabe
}

Art Nouveau jewellery created by René Lalique is presently corroded. To identify the corrosion processes, $\mathrm{Au}-\mathrm{Ag}-\mathrm{Cu}$ alloys with compositions comparable to those used in René Lalique's jewellery were fabricated to be exposed to sulphide-containing environments. Using SEM-EDS, XRD, UV-Vis spectroscopy and ellipsometry, it was for the first time demonstrated that at the surface of tarnished Au alloys forms a corrosion film with a layer-by-layer structure. Considering the complex refractive indices of bulk $\mathrm{Cu}$ and $\mathrm{Ag}$ oxides and sulphides, a two-step corrosion mechanism was proposed. The formation of $\mathrm{Cu}$-based compounds during the early corrosion stages is followed by the formation of Ag-based compounds. The thickness of the formed film, shown for one of the gold alloys to be $80 \mathrm{~nm}$, is due to the corrosion kinetics controlled by the presence of $\mathrm{Au}$ and by the formation of a Au-S self-assembled monolayer. The corrosion mechanism of gold alloys raises a new conservation challenge concerning the removal of nanometric layers.

\section{Introduction}

When modified by atmospheric corrosion, gold alloys have a dull appearance and undergo a colour variation from red to brownish-black. The corrosion process might, with time, cause damage to objects..$^{1-3}$ Surface modification has a direct impact on the aesthetic perception that the public has of the objects exhibited in museums. An example of this situation is the collection of Art Nouveau jewellery created by René Lalique (1860-1945) exhibited at the Calouste Gulbenkian Museum in Lisbon. ${ }^{4}$ Currently, over fifty of the eighty jewels show more or less large coloured areas with different appearances. For example, the corsage ornament Serpents (Fig. 1) in gold and enamel, shows red coloured areas (Fig. 2).

The coloured corroded gold alloy surfaces have been mainly ascribed to the presence of $\mathrm{Ag}_{2} \mathrm{~S},{ }^{3}$ an expected corrosion product, as sulphur-based compounds, such as $\mathrm{H}_{2} \mathrm{~S}$ and $\mathrm{SO}_{2}$, are current pollutants in museum environments., ${ }^{5,6}$ Other corrosion products such as $\mathrm{CuS}, \mathrm{Cu}_{2} \mathrm{~S}, \mathrm{Ag}_{2} \mathrm{O}, \mathrm{AuAgS}$ and $\mathrm{Ag}_{3} \mathrm{AuS}_{2}$ have also been identified in the corroded layers of objects made from gold alloys exposed to high sulphide

\footnotetext{
${ }^{a}$ Archeofactu, Rua do Cerrado das Oliveiras, 14, 2Dto, 2610-035 Alfragide, Portugal. E-mail: isabel.tissot@archeofactu.pt

${ }^{b}$ LIBPhys - UNL, Campus da Caparica, 2829-516 Caparica, Lisboa, Portugal ${ }^{c}$ Centro de Química Estrutural, Centro de Química e Bioquímica, Faculdade de Ciências, Universidade de Lisboa, Campo Grande, 1749-016 Lisboa, Portugal. E-mail:jmcorreia@fc.ul.pt; ocmonteiro@fc.ul.pt

${ }^{d}$ LNEG, LEN/UER, Estrada do Paço do Lumiar, 22, 1649-038 Lisboa, Portugal. E-mail: alexandra.barreiros@lneg.pt

${ }^{e}$ UMR 8096 CNRS - ArchAm, MAE, 21 allée de l'Université, 92023 Nanterre, France.

E-mail: maria.guerra@cnrs.fr
}

containing atmospheres. ${ }^{7-9}$ The dependence of the colour variation on the corrosion layer thickening was also emphasised. For high-purity gold $(\mathrm{Au}>99 \mathrm{wt} \%$ ) 5-350 nm thicknesses were

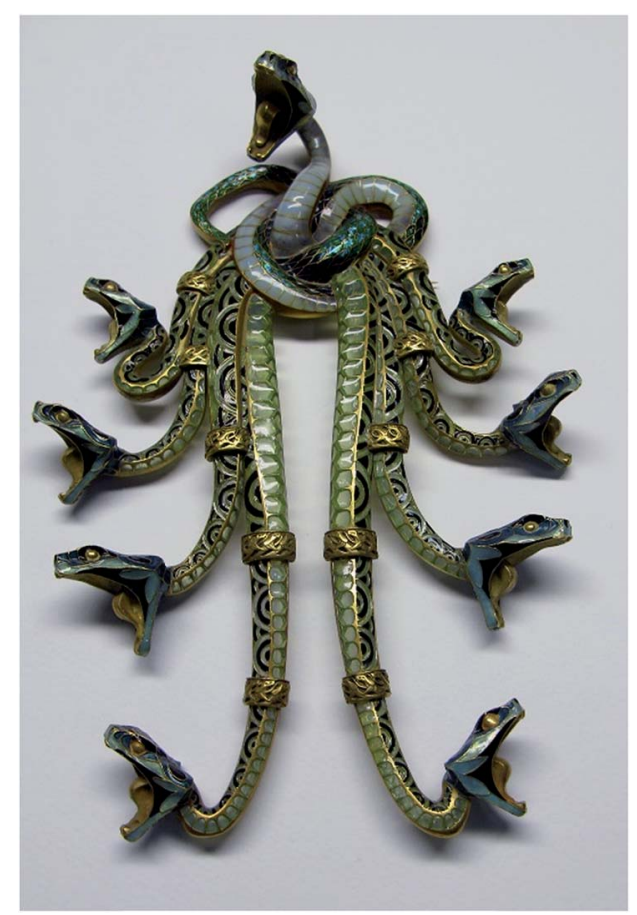

Fig. 1 Corsage ornament Serpents created by René Lalique in 19031904 (Acc.n.1216), Calouste Gulbenkian Museum, Lisbon (photography M. F. Guerra). This is one of the most representative René Lalique's creations, who applied materials like enamels, stones and mother of pearl on silver and gold substrates. ${ }^{11,12}$ 